\title{
The Use of Board Game to Improve Students' Writing Skill of the Descriptive Text at SMPN 18 Surabaya
}

\author{
Rukiyah \\ SMPN 18 Surabaya, email: rukiyahp1871@gmail.com
}

\begin{abstract}
The study examined the implementation of board games through the students' achievement in writing skill through descriptive text at SMPN 18 Surabaya. It used the pre-test post-test design in classroom action research model for the students in class VIII-G as subjects selected from sampled classes. T-test was used as the statistical technique for the data analy sis. The hypotheses were tested at 0.05 level of significance. The results showed the data in the tables t-Test: Paired Two Sample for Means (VIII-G) reveal that the obtained t-value was -10.83171521 which were well above the limit of 0.05 of significance. The post-test had a higher mean of 80.39473684 . While the pre-test had a mean of 69.36842105 . Because $p$-value (4.97263E-13) was less than the standard significance level of 0.05 , researchers can reject the null hypothesis (Ho). Thus, the second hypothesis (Ha) was accepted regarding there is significant effect of the implementation of board games through the students' achievement in writing skill through descriptive text. It is hereby recommended that English teachers should adapt this model to enhance students' achievement in other English skills. For students, it is suggested they have to be more paying attention to the model of teaching being applied such as the implementation of board games through the students' achievement in writing skill through descriptive text so they can be able to explore their skill of writing as well. Other researches, however, should explore to investigate the effect of other games on specific writing genres.
\end{abstract}

Keywords: board game, writing skill, descriptive text

\section{INTRODUCTION}

Written language is one of language products as well as the means of communication that can be expressed through written products which needs specialized skills. The written products can be measured as the students' achievement in a process of learning the language (Utami, 2012, p. 1). As a result, writing skills become an important part in students' English learning process. However, the teaching learning English in the schools does not give satisfactory proportion of writing skills. Writing skills are less taken into consideration in the teaching process than the other skills. For example, teachers often ask students to read certain texts and answer the following question instead of asking them to produce a text. This condition of learning makes the students feel writing skills seem not very important. Consequently, the problems aroused become a complication for the students to gain a good result on their writings.

Writing skill is a productive skill which focuses introducing and creating information in written form. As productive skills, the term of speaking and writing skill, are essential in 
gaining information where students actually have to produce language themselves (Harmer, 2007, p. 265). Furthermore, it is argued process of starting with an idea ends up as words on a page allowing them to learn more opportunity in thinking about the language, whether they are involved in study or activities. In English language education, writing is often related to composing a paragraph or a text. To make a written text, there are many matters which have to consider such as the content, the word choice, text organization, the mechanics, the grammar and syntax.

Nevertheless, creating a good writing product is no easy thing to be done. This might be due to the lack of the knowled ge and the difficulty to express the ideas. Nunan (2005, p. 88) argues writing can be described as a mental work of inventing ideas, thinking about how to express thoughts, and organizing concepts into statement and paragraphs that will be clear more to readers. It is implied writing needs knowledge about its procedure in order to make a good work in case of sharing ideas through written works, and to arrange the words into a good paragraph. Subsequently, if teacher always helps the students to practice their writing skill, they will be easy to create the product of writing.

In fact, students have learnt writing English since primary school but most of them cannot write well. Based on pre observation done by researcher in January 2020 at SMPN 18 Surabaya, the students of the eight-grade class VIII-Ghad difficulties in writing the descriptive texts in which they frequently were being confused of what to write and how to start. This condition affected the students' achievement in writing descriptive text. It is needed some creative and engaged strategies to solve the problem. Writing descriptive text becomes one of the problems in the students. The most difficult for them is how to describe a person or a thing since it has some rules to be followed. As a result, they couldn't achieve the Minimum Mastery Criteria $(K K M)$ which was lower than 75 .

To overcome that problem, the researcher decided to apply a kind of media in order to make the students more interested in writing and helped the students easier in generating their idea before write and arranging word by word into a good paragraph by applying a game. Game is one of media which can we use in teaching and learning activity, especially in writing descriptive text. Lee (2005) argued games develops a strategy in improving positive attitudes towards learning English. There are many categories of games can be applied during the learning process which can be conducted so that the students are more active in the learning process in the classroom, especially in writing activities, is through game such as a board game. 
A board game is known as a game which is suitable to use and can be applied in groups so the students can express their idea using English with their friends in enjoyable way. Students can build the characters of working cooperatively, be self-confident, creative, responsible, honest, and passionate in learning by learning in groups (Jayanti \& Murdibjono, 2013). In addition, a magic board game is a type of game played by students in learning activities in case of placing or moving pieces of words, phrases, sentences on a board provided by the teacher based on the directions given. Studying with board games might be more stimulating since it also necessitates students' attractiveness. Their excitement to become the best among their groups will motivate them to study better. Concerning to the background of the research mentioned, the researcher conducted the research entitled: "The Use of Board Game to Improve Students' Writing Skill of the Descriptive Text at SMPN 18 Surabaya”. This research aimed to describe the implementation of board games through the students' achievement in writing skill through descriptive text at SMPN 18 Surabaya. Then, this research proposed twohypotheses called Ho: if there is significant effect in the implementation of board games through the students' achievement in writing skill through descriptive text and Ha: if there is no significant effect in the implementation of board games through the students' achievement in writing skill through descriptive text.

\section{LITERATURE REVIEW}

\section{Board Game}

Hadfield (1996, p. 5) stated "Board games and card games are familiar game types, where both of them demand the players to be first rounding the board." In addition, it is assumed board games are also a type of games includes battle of the players to reach the winning position. A board game is a game that involves counters or pieces moved or placed on a pre-marked surface or "board", according to a set of rules. Games can be based on pure strategy, chance (e.g. rolling dice), or a mixture of the two, and usually have a goal that a player aims to achieve.

Metom (2013, p. 404) claimed "The board game has similar concept with snakeand-ladder game. A board game includes a game board, cards consist of grammar options, movers, a dice, and an answer booklet." They further explain that before the game is played, students are briefed with the rules of the game. The players then roll the dice. They have to answer the question based on where they are landed. If the answer is correct, the player will 
have chance to roll the dice once more, and if the answer is incorrect, they will miss a turn. However, the rules can be freely modified.

\section{Writing}

Writing is a productive skill which means it acts to produce the language in the written form. Writing itself is indeed an active skill as in the act of creating a text, people need to do some steps like setting goals, generating ideas, organizing information, selecting appropriate language usage and use, making a draft, reading and reviewing it, then revising and editing (Hedge, 2000, p. 308). Writing reinforces the grammatical structures, idioms, and vocabulary, provides opportunities for the students to challenge themselves of using the language, and enables the students develop language skills in terms of fluency, accuracy, and appropriateness in communicating their messages (Hughey, Wormuth, Hartfiel, \& Jacobs, 1983).

Writing process operated in four stages. Harmer's writing processes consist of planning, drafting, editing, and final version. The steps can be explained further as follows: (a) planning, (b) drafting, (c) editing (reflecting and revising) and (d) final version (Harmer, 2004). Writing needs the activation of the other skills and it is said to be a difficult skill to master. In addition, writing is placed the last among the fourth in the learning. The difficulty of writing is also caused by the requirements of the knowled ge of grammar and vocabulary and clear organized presentation of ideas. He further explains that because of the difficulty, pupils tend to have lack of the motivation for learning writing (Celce-Murcia, 1991).

\section{Descriptive Text}

Descriptive text is a text that describes a particular person, place or thing. Descriptive text differs from other text in terms of its generic structure and language features. It is used to describe a place or thing using facts. Wardiman, et. al. (2008) specified the generic structure of descriptive text into two parts called 'identification' and 'description'. In identification, the writer identifies the phenomenon to be described. Identification is like orientation in other genres of text. It is usually put in the first paragraph and brings us to know about the discussed topic. In description, the writer describes the parts of things, parts of physical appearance, qualities (degree of beauty, excellence, worth or value), and other characteristics (prominent aspects that are unique). It is put after identification or next paragraph of identification until final paragraph. 


\section{METHOD}

\section{Research Design}

Based on the purpose of the study that is to describe the implementation of board game through the students' writing skill of the descriptive texts at SMPN 18 Surabaya, this research is classified as action research held on February $3^{\text {rd }}, 2020$ to March $6^{\text {th }}, 2020$. According to Kemmis and McTaggart (1990) action research is "a form of collective selfreflective inquiry undertaken by participants in social situations in order to improve the rationality and justice of their own social or educational practices, as well as their understanding of these practices and the situations in which these practices are carried out". It is concluded action research is a study to improve social or education practices. Parsons and Brown (2002), stated that action research is a form of investigation designed for use by teachers to attempt to solve problems and improve professional practices in their own classrooms. It involves systematic observations and data collection which can be then used by the practitioner-researcher in reflection, decision-making and the development of more effective classroom strategies. Shortly, Action Research is a kind of research that is conducted to critic and to improve something.

\section{Research Subjects}

The population of the study was the $8^{\text {th }}$ grade students at SMPN 18 Surabaya in the Academic Year 2019/2020. The subjects of the study were the class VIII-G students of SMPN 18 Surabaya consisting 38 students.

\section{Data}

The sources of data were all of students and teacher activity during the implementation of board game through teaching descriptive texts. Students' results of the test in pre-test and post-test were the data of the study.

\section{Instruments}

The pre-test was administered to the subjects of the research at the first meeting before the treatment was started. The post-test was given to the subjects after the treatment to find out their progress in writing descriptive text after the implementation of the board game. 


\section{Data Collection Procedure}

There are two kinds of data collected for this research, namely qualitative and quantitative data. The data are be presented more qualitatively, however, with the quantitative data as the supporting ones. Qualitative data are described the situation and the findings of the research in the form of sentences while the quantitative data are described in the form of scores. The qualitative data were gathered through several techniques. The first one was observation conducted from the beginning of the research. The researcher wrote down the observation in an observation checklist and the data were presented in field notes. The quantitative data were obtained through writing rubric from the writing tests. The tests showed scores of the students from the beginning of the research until the implementation of the action. This showed the differences that were later to be compared and described in the form of sentences.

\section{Data analysis Technique}

Burns (2010: 104) proposes five steps for analyzing data of an Action Research. They are assembling the data, coding the data, comparing the data, building meanings and interpretations, and reporting outcomes. In this research, the researcher collected the data that have been gathered from the observations. Then, the researcher categorizes the data that has been collected into more specific patterns. The researcher compared the data from different instruments and sees if they say the same thing or show some contradictions. Next, the researcher interpreted deeply about what the data are saying and develops an explanation about what the research means at a boarder level. Lastly, presented the research to others from the beginning to end, not just the analysis and findings.

To analyze quantitative data, the researcher compared the results of students writing scores from Cycle 1 before and after the implementation of the games, and also from Cycle 2 after the implementation of the games. The scores were calculated and compared to find any change of the students' writing skills. First writing scores of the first product were summed, as well second and third products. Then the researcher calculated the average of each test' scores and compare them to find if there was any improvement. The average of the data was calculated with the formula proposed by Arikunto (2007: 264). 


\section{RESULTS}

\section{Findings}

The objective of this study was to describe the implementation of board game through teaching descriptive text to improve students' writing at SMPN 18 Surabaya. Data were mainly generated through writing's test results that evaluated students' writing samples before they got the treatment of board game compared to their writing after they completed treatment of the implementation of board game in teaching descriptive text. The scores of the subjects' in writing before and after they received the board game viewed on the table 1 as below:

Table.1 Students' Scores

\begin{tabular}{|c|l|c|c|}
\hline \multirow{2}{*}{ NO } & \multirow{2}{*}{ Subjects } & \multicolumn{2}{|c|}{ Scores } \\
\cline { 3 - 4 } & & Pre-Test & Post-Test \\
\hline \hline 1 & Anang Tri Saputra & 65 & 80 \\
\hline 2 & Antinur Octafia & 72 & 78 \\
\hline 3 & Daniel Marvelino Al Dwindo & 68 & 76 \\
\hline 4 & Desi Mifta Amelia & 76 & 82 \\
\hline 5 & Devara Prasanti Maharani & 80 & 90 \\
\hline 6 & Devi Indah Jayanti & 70 & 92 \\
\hline 7 & Dony Pratama & 70 & 80 \\
\hline 8 & Egit Trinindia & 65 & 86 \\
\hline 9 & Fadilla Alensia Agustin & 64 & 82 \\
\hline 10 & Fery Dwi Purnomo & 76 & 80 \\
\hline 11 & Khoyrunnisa & 68 & 80 \\
\hline 12 & Marcya Aldera Putri Shafira & 65 & 85 \\
\hline 13 & Mega Risli Pangestu & 74 & 85 \\
\hline 14 & Mohammad Mirzha & 65 & 80 \\
\hline 15 & Mohkamad Riffai & 70 & 80 \\
\hline 16 & Muhammad Akbar Maulana & 65 & 88 \\
\hline 17 & Muhammad Nur Fauzi & 78 & 76 \\
\hline 18 & Muhammad Rizq Febbyanzah & 76 & 76 \\
\hline 19 & Naufaldy Ari Manggala & & 80 \\
\hline 20 & Pancarani Wulandari & 75 & 80 \\
\hline 21 & Panji Satria Hardiansyah & \multicolumn{2}{|c|}{} \\
\hline 22 & Prista Atma Prabawati & \multicolumn{2}{|c|}{} \\
\hline
\end{tabular}




\begin{tabular}{|c|l|c|c|}
\hline 23 & Putri Febrianti Ayuningtyas & 60 & 75 \\
\hline 24 & Putri Nur Hafifah & 72 & 80 \\
\hline 25 & Rachmat Rasyid Ardiono & 65 & 76 \\
\hline 26 & Rafi Dwianto & 66 & 88 \\
\hline 27 & Rajendra Jala Pradana Muslim & 70 & 88 \\
\hline 28 & Riky Saputra & 72 & 76 \\
\hline 29 & Rizal Harjuna Guntur & 72 & 80 \\
\hline 30 & Rudi Santoso & 60 & 80 \\
\hline 31 & Rudy Setiawan & 66 & 78 \\
\hline 32 & Salshabila Kartika Octaviani & 65 & 76 \\
\hline 33 & Sephia Nur Indahwati & 72 & 75 \\
\hline 34 & Sinta Dewi Aziza & 65 & 76 \\
\hline 35 & Wahyu Enggar Pratama & 72 & 80 \\
\hline 36 & Windi Afifah & 76 & 76 \\
\hline 37 & Yuni Aisiyah & 70 & 76 \\
\hline 38 & Hernando Khalifah Sinnatria Putra & 65 & 76 \\
\cline { 2 - 4 } & & $\mathbf{6 9 . 3 7}$ & $\mathbf{8 0 . 3 9}$ \\
\hline \multirow{2}{*}{ Average } & & \\
\hline & & 72 & 76 \\
\hline
\end{tabular}

The test of significance of difference between mean scores for writing before and after they received the implementation of board game in teaching descriptive text was performed using the following $\mathrm{t}$ test:

Table.2 t-Test: Paired Two Sample for Means (VIII-G)

\begin{tabular}{lrr} 
& \multicolumn{1}{c}{ Pre-Test } & \multicolumn{1}{c}{ Post-Test } \\
\hline Mean & 69.36842105 & 80.39473684 \\
\hline Variance & 27.75248933 & 22.46159317 \\
Observations & 38 & 38 \\
Pearson Correlation & 0.217012324 & \\
Hypothesized Mean Difference & 0 & \\
df & 37 & \\
t Stat & -10.83171521 & \\
P(T<=t) one-tail & $2.48631 E-13$ & \\
t Critical one-tail & 1.68709362 & \\
P(T<=t) two-tail & $4.97263 \mathrm{E}-13$ & \\
t Critical two-tail & 2.026192463 & \\
& Pre-Test & Post-Test \\
\hline
\end{tabular}

The output indicates that mean for Pre-test is 69.36842105 and for Post-test it is 80.39473684. The data in the above table t-Test: Paired Two Sample for Means (VIII-G) reveal that the obtained $t$-value is -10.83171521 which is well above the limit of 0.05 of 
significance. For the results, the researchers used $\mathrm{P}(\mathrm{T}<=\mathrm{t})$ two-tail, which is the $\mathrm{p}$-value for the two-tailed form of the t-test. Because p-value (4.97263E-13) is less than the standard significance level of 0.05 , researchers can reject the null hypothesis (Ho). Thus, Ha is accepted. The sample data support the hypothesis that the population means are different. Specifically, Post-test's mean is greater than Pre-test's mean. This means that the writing scores of students have increased significantly as the result of the implementation of the board game towards students' writing descriptive skill.

This result can be cited to verify the major hypotheses of the study that students' writing ability has significantly improved as a result of the implementation of board game through descriptive text to support their writing process. This same result can be used to answer the main question of the study which inquiries about the effect of using the board game through on teaching writing descriptive text to the students (Class VIII-G) at SMPN 18 Surabaya. It is obvious that the implementation of board game has helped the students to significantly improve their writing ability.

\section{Discussion}

This research was designed to describe the implementation of board game through teaching descriptive text to improve students' writing of descriptive text the class VIII-G at SMPN 18 Surabaya in the academic year 2019/2020. Based on the results of paired sample t-test between pretest and posttest of the implementation of board game, it was found that the implementation of board game provided significant effect on students' writing skill of the descriptive text. Most significantly, when teacher used board game to teach writing to students, they must model their instruction tasks before they require their students to do these tasks independently. Indeed, teachers needed to serve as a facilitator for students' learning. Writing is the most complex process for students especially in junior high school students in SMPN 18 Surabaya, and in order to help these students handle this awkward task, teachers needed to guide them carefully and provide them with every possible support to develop their writing skill.

The result of t-Test showed a significant main effect of treatment on students' achievement in writing skill of descriptive text for the class VIII-G at SMPN 18 Surabaya. It also showed that the implementation of board game facilitated learning more than the conventional teaching approach. This agrees with the assertion that the conventional teaching strategy is unproductive (Okeke, 2008 in E., 2016) and unproductive in evolving 
theoretical thoughtful of subject matter. The use of board game in this research engaged students' skill to be active cognitively in writing.

Analysis of hypothesis reveals a significant difference in the pre-test and post-test score of the students. The post-test had a higher mean of 80.39473684 while the pre-test had a mean of 69.36842105 . Because p-value (4.97263E-13) in t-test's result is less than the standard significance level of 0.05 , researchers can reject the null hypothesis (Ho). Thus, the second hypothesis (Ha) was accepted. Analysis of the hypothesis in the results of t-test reveals that there is a significant effect in the writing skill of descriptive text to the students in class VIII-G at SMPN 18 Surabaya taught using board game.

\section{CONCLUSION}

The result of the analyses carried out on the research hypotheses using appropriate description and inferential statistics showed the board game as it was implemented, hence it can be said board game helped to facilitate both learning and preservation. The use of activitybased teaching strategy like board game, make students to be more active and meaningful learning were achieved. Thus, this implementation of board game develops students' achievement in writing skill of descriptive text. The results of this study showed the post-test had a higher mean of 80.39473684 while the pre-test had a mean of 69.36842105 . Because pvalue (4.97263E-13) in t-test's result was less than the standard significance level of 0.05 , researchers can reject the null hypothesis (Ho). Thus, the second hypothesis (Ha) was accepted regarding there is of implementation of board game in teaching descriptive text on students' achievement in writing skill.

This study had limited discussion that has focused on the implementation of only the board game inn teaching writing descriptive text. It is hereby recommended that English teachers should adapt the model of research to enhance achievement in other English skills. For students, it is suggested that they have to be more paying attention to the model of teaching being applied such as the implementation of board game so they can be able to explore their skill of writing as well. Other researches, however, should try to investigate the effect of other games on specific writing genres such as recount, report, persuasive, narrative and expository writing. 


\section{REFERENCES}

Celce-Murcia, M. (1991). Teaching English as a Second or Foreign Language . New York: Newbury House.

Harmer, J. (2007). The Practice of English Language Teaching, 4th Edition. New York: Cambridge University Press.

Hedge, T. (2000). Teaching and Learning in the Language Classroom. Oxford : Oxford University Press.

Hughey, J. B., Wormuth, D. R., Hartfiel, V. F., \& Jacobs, H. L. (1983). Teaching ESL Composition: Principles and Techniques. Cambridge: Newbury House Publishers.

Jayanti, N. M., \& Murdibjono, A. (2012). Developing A Board Game for Speaking Activities. Retrieved April 20, 2020, from http://jurnalonline.um.ac.id/data/artikel/artikelA2955306F88A12873ED9009706F04A70.pdf

Kemmis, S., \& McTaggart, R. (1982). The Action Research Planner. Geelong, Victoria: Deakin University Press.

Lee, I. (2005). Error correction in the L2 writing classroom: What do students think? . Canada: TESOL Canada Journal, 22, 1-16. .

Nunan, D. (2005). Practical English Language Teaching: Young Learner. New York: McGraw Hill.

Parsons, R. D., \& Brown, K. S. (2002). Teacher as Reflective Practitioner and Action Researcher. Belmont: Wadsworth/Thompson Learning.

Utami, A. B. (2012). Improving Students' Writing Skills on Recount Texts through Collaborative Writing Technique (Classroom Action Research on Grade Eight of SMP N 2 Sentolo in the Academic Year of 2011/2012). Yogyakarta: Yogyakarta State University. 